\title{
Öğretmen Adaylarının Çevrimiçi Ortamda Öğrenmeye Yönelik Hazır Bulunuşlukları*
}

\section{Mustafa Serkan GÜNBATAR**}

Öz: Bu çalışmada amaç öğretmen adaylarının çevrimiçi ortamda öğrenmeye karşı hazır bulunuşluklarını tespit etmektir. Çalışma var olan bir durumu olduğu gibi betimlemektedir. Katılımcılar, 2015-2016 güz yarıyılında Türkiye’ deki bir Eğitim Fakültesinde Pedagojik formasyon eğitimi almakta olan öğrencilerden oluşmaktadır. Çalışma grubu öğrencileri görüşmelere gönüllülük esasına göre katılmışlardır, yedisi kadın ikisi erkektir. Veriler öğretmen adaylarına sorulan görüşme formu kapsamındaki sorular ile odak grup görüşmeleri aracılığıyla elde edilmiştir. Yöneltilen sorular alan yazına bakılarak oluşturulmuş ve bir alan uzmanı tarafından gözden geçirilmiştir. Sorular "İletişim öz yeterliliğì", "Kurumsal Destek”, “Öğrenme öz yönlendirmesi” ve “Öğrenmeyi transfer öz yeterliliği” boyutları çerçevesinde oluşturulmuştur. Elde edilen veriler betimsel olarak analiz edilmiştir. Bulgular incelendiğinde öğrencilerin toplamda 68 olumlu, yedi nötr, 20 tane de olumsuz düşünceye sahip oldukları görülmüştür. Oranlama yapıldığında olumlu ifadelerin olumsuzların yaklaşık üç buçuk katı olduğu tespit edilmiştir. Bu sonuçtan hareketle katılımcıların çevrimiçi ortamda öğrenmeye hazır bulunuşluklarının yeterli düzeyde olduğu yorumu yapılmıştır.

Anahtar Kavramlar: Çevrimiçi öğrenme, hazır bulunuşluk, öğretmen adayları.

\footnotetext{
*Çalışma, Twelfth International Congress of Qualitative Inquiry' de sözlü bildiri olarak sunulmuştur **Yrd.Doç.Dr., Yüzüncü Yıl Üniversitesi, Eğitim Fakültesi BÖTE, Van-Türkiye, e-posta: mustafaserkan@yyu.edu.tr

$\begin{array}{lll}\text { Gönderim:29.02.2016 } & \text { Kabul:14.02.2017 } & \text { Yayın:03.04.2017 }\end{array}$
}




\title{
Pre-service Teachers' Readiness for Online Learning
}

\begin{abstract}
The purpose of this study was to determine pre-service teachers' readiness for online learning. In this study, existing situation has been descripted. Descriptive survey method was used. The participants of the study were pre-service teachers taking teaching certification through online education in the fall semester 2015-2016. All of the participants took part in the study voluntarily. Seven of the participants were female, two of them male. The data were collected through the focus group interviews including questions about the readiness for online learning. The interview questions were formed in light of the literature and examined by the expert in this field. The questions were organized under four categories, namely, "communication self-efficacy", "institutional support", "self-directed learning", and "learning transfer self-efficacy". Obtained data are grouped under the category of positive, negative and neutral. There are 68 positive, 7 neutral and 20 negative expressions. When proportioned, positive statements are approximately three and half times more than negative statements. By this results we can say participants' readiness for online learning is at sufficient level.
\end{abstract}

Key words: Online learning, readiness, pre-service teachers. 


\section{Giriş}

Günümüzde uzaktan eğitimin öğretmen ve öğrencilerin farklı ortamlarda bulunduğu, öğretim içeriğinin ise bilgi ve iletişim teknolojilerinin sağladığı imkânlar sayesinde paylaşıldığı bir süreç şeklinde olduğu ifade edilebilir. Uzaktan eğitimin güncel uygulamaları göz önünde bulundurulduğunda ise en yaygın şekillerinden birinin çevrimiçi ortamda gerçekleştirilen halinin olduğu görülebilir. Çevrimiçi öğrenme faaliyetlerinin bazı değişkenler açısından değerlendirilmesi ile eğitim teknolojileri disiplini için önemli bulgular elde edilebilir.

Alan yazındaki çevrimiçi öğrenmeyi değerlendirmek için ortaya konan modeller incelendiğinde bunların kapsadıkları öne çıkan elementlerin "teknoloji”, “içerik”, “insan kaynakları", “denetleme ve ölçüm”, “organizasyon ve yönetim”, “destek ve servisler”, "kanunlar ve düzenlemeler", "mali hususlar", "güvenlik ve politika" olarak ifade edilebilecekleri görülmektedir (Darab \& Montazer, 2011). Başarılı bir çevrimiçi öğrenme deneyimi için öğrencilerin hazır bulunuşluğunun arttırılmasının temel olduğu ileri sürülebilir (Xiong, So, \& Toh, 2015). Hazır bulunuşluk noktasında yapılacak değerlendirmeler ile çevrimiçi ortamların insan kaynakları boyutu ile ilgili önemli veriler elde edilebilecektir.

Çevrimiçi öğrenmeye hazır bulunuşluk ile ilgili faktörler üç grup altında toplanabilir. Bunlar, teknik faktörler (donanım, yazılım, içerik, internet erişimi, bant genişliği), örgütsel faktörler (uzmanlar, kurallar, örgüt kültürü, yönetim performansı) ve sosyal faktörler 
(toplumun e-öğrenme algısı, kanunlar, idari talimatlar) şeklindedir (Keramati, Afshari-Mofrad \& Kamrani, 2011). Bu faktörleri kapsayıcı şekilde çevrimiçi öğrenmeye hazır bulunuşluluk “İletişim özyeterliliği”,, "Kurumsal Destek”, “Öğrenme öz yönlendirmesi” ve “Öğrenmeyi transfer öz yeterliliğì” şeklinde ifade edilebilecek başlıklar altında incelenebilir (Hung, 2016).

Bandura öz yeterlilliği, öğrenenin belirlenen hedeflere ulaşmak için ders içeriğini düzenleme ve uygulamaya koyma becerisine kişisel olarak karar vermesi şeklinde tanımlamaktadır (Zimmerman, 2000). Teknoloji deneyimi daha fazla olan öğrencilerin eöğrenme algıları daha olumlu olmaktadır (Smart \& Cappel, 2006) ve topluluk hisleri ne kadar güçlüyse, bununla ters orantılı olarak kendilerini izole hissetmektedirler (Song, Singleton, Hill \& Koh, 2004). Çevrimiçi öğrenme hazır bulunuşluğu, öğrenciler arasındaki iletişim gibi durumlardan pozitif şekilde etkilemektedir (Horzum, Kaymak \& Gungoren, 2015; Talsik, 2015). Öğrenenlerin çevrimiçi öğrenme ortamında birbirleri ile ve öğretim elemanı ile olan iletişimlerinin nasıl olduğunu anlamak gün geçtikçe önem kazanmaktadır. Çünkü bu ortamlarda yapılan tartışmalar öğrenme düzeyleri için önemli bir kritik bir öneme sahiptir (Hung, 2016). Çevrimiçi öğrenmeye hazır bulunuşluğa etki eden faktörlerden birisi de etkileşim ve iletişimdir (Ilgaz \& Gülbahar, 2015). Çevrimiçi öğrenme hazır bulunuşluğunun artması öğrenme ortamındaki etkileşimi arttırmakta, hazır bulunuşluğun azalması etkileşimi azaltmaktadır (Kaymak \& Horzum, 2013). Öğrenenlerin çevrimiçi ortamdaki iletişim öz yeterlilik algıları çevrimiçi ortamda öğrenmeye hazır bulunuşlukları için önemli bir faktör olarak karşımıza çıkmaktadır.

Çeşitli paydaşları bulunan çevrimiçi öğrenme sürecini daha etkili uygulamak ve kullanmak isteyen yöneticiler bu ortamlar için iyi bir örgütsel çevre sunmalıdırlar (Keramati, Afshari-Mofrad \& Kamrani, 2011). Çevrimiçi ortamlarda "içerik tasarımcısı ve 
düzenleyicisi”, "tartışma kolaylaştırıcı", "sosyal destekçi”, “teknoloji kolaylaştırıcı" ve “ölçüm tasarımcısı” şeklinde görevler üstlenen (Hung \& Chou, 2015) öğretmenlerin eöğrenme kullanışlılık ve fayda boyutlarından öğrencilere oranla daha fazla etkilenmektedirler (ŠUmak, B., HeričKo, M., \& PušNik, M., 2011). Dolayısıyla öğretmenlerin çevrimiçi öğrenme ortamlarını kabullerini etkileyen değişkenlerden birisi öğretim süreci öncesindeki beklentileridir (Hrtoňová, Kohout, Rohlíková \& Zounek, 2015). Fakat, e-öğrenmenin en önemli bileşeni öğrencilerdir. Öğrencilerin e-öğrenme kabullerini tespit etmek için kolaylaştırıcı durumlar (facilitating conditions) göz önünde bulundurulması gereken unsurlardan birisidir (Teo, 2010). Bununla ilintili olarak öğrenciler çevrimiçi öğrenme ortamında kurumsal faktörlerden etkilenmektedirler (Ilgaz \& Gülbahar, 2015). Kurumsal destek öğrenenlerin derse devam etmeleri için önemli belirleyicilerdendir (Park \& Choi, 2009). Alanyazın incelendiğinde kurumsal destek öğrenme ortamlarında öğrenenlerin bazı davranışları sergilemelerine yardımcı olan veya bu davranışları engelleyen faktörlere karşılık gelmektedir (Hung, 2016). İşbirliğine dayalı eğitim ortamlarında kurumsal destek üstlerin sağladığ 1 destek (superiors' support), akran desteği (colleagues'support) ve olumlu kurumsal iklim (positive organizational atmosphere) olmak üzere üç bileşenden oluşur (Joo, Joung \& Sim, 2011). Üstlerin sağladığı destek danışmanın öğrenene olan olumlu desteklerine; Akran desteği öğrenenlerin öğrenme sürecinde birbirlerine olan yardımlarına; Kurumsal iklim ise öğrenme ortamındaki diğer unsurlara (çalışanlar vb.) karşılık gelmektedir. İletişim ve etkileşimin söz konusu olduğu çevrimiçi öğrenme ortamlarında öğrenenlerinin öğrenmeye hazır bulunuşlukları için kurumsal destek faktörü bir diğer önemli bileşendir.

Erişkin öğrenenler bazı deneyimlere sahiptirler, kendi kendilerini yönlendirebilirler ve bağımsızdırlar (Cercone, 2008). Çevrimiçi öğrenme ortamları öğrenenlere daha önce hiç olmadığı kadar sorumluluk yüklemektedir. Öğrenenlerin kaynakları etkili kullanarak kendi 
öğrenmelerinin sorumluluğunu almalarını gerekli kılmaktadır (Lin \& Hsieh, 2001), dolayısıyla çevrimiçi öğrenme erişkin öğrenenler için uygun bir ortam sunabilmektedir. $\mathrm{Bu}$ ortamlarda başarı için en önemli unsur öz yönelimli öğrenmedir (Kırmızı, 2015). Öğrenme öz yönlendirmesi, öğrenenlerin başkalarından yardım alarak veya almayarak kişisel öğrenme ihtiyaçlarını teşhis etmeleri, hedef belirlemeleri, insan ve maddi kaynakları belirlemeleri, uygun öğrenme stratejilerini seçme ve uygulamaları ile öğrenme çıktılarını değerlendirmeleri şeklindeki eylemleri ile insiyatif aldıkları süreç olarak tanımlanabilir (Loyens, Magda \& Rikers, 2008). Çevrimiçi öğrenme ortamlarında öğrenci doyumuna etki eden en önemli faktör motivasyondur (Kırmızı, 2015) ve çevrimiçi öğrenme hazır bulunuşluk düzeyleri akademik motivasyon tarafindan tahmin edilebilmektedir (Horzum, Kaymak \& Gungoren, 2015). Öğrenme hedefine aktif olarak entegre olmayı, hazırlanan planı uygulamayı, öğrenme sürecinde kendi kendini değerlendirmeyi, üstbilişsel stratejileri aktif kılmayı içeren duyuşsal özellikler öğrenme öz yönlendirmesi için elzem bir unsurdur ve içsel motivasyon ile bağlantılı olarak karşımıza çıkar (Loyens, Magda \& Rikers, 2008). Öğrenenlerin kişisel özellikleri göz önünde bulundurulduğunda, öğrenme öz yönlendirmesi çevrimiçi öğrenme ile tamamen ilişkili bir kavramdır (Hung, 2016) ve bu ortamda öğrenmeye hazır bulunuşluk için önemli bir bileşendir

Erişkin öğrenenler öğrenme ortamından aldıklarını başka ortamlara taşıyacak bireylerdir (Cercone, 2008). Öğrenmeyi transfer öz yeterliliği motivasyon, çalışma ortamı, beceri ve öğrenen özellikleri olarak ifade edebileceğimiz dört boyut altında incelenebilir (Chen, Holton III, \& Bates, 2005) ve bu durumlar göz önünde bulundurularak tespit edilebilir. Öğrenmeyi tranfer öz yeterliliği ders kapsamında edinilen bilgilerin meslek hayatında uygulanabilmesine ilişkin durumları barındırmaktadır. Dolayısıyla çevrimiçi öğrenme 
deneyimine sahip bireylerin bu ortamda öğrenebilmeye hazır bulunuşluklarını tespit edebilmek için bir diğer faktör olarak değerlendirilebilir (Hung, 2016).

Türkiye'de öğretmen adaylarına çevrimiçi ortamda sunulan derslerin çeşitli örnekleri bulunmaktadır. $\mathrm{Bu}$ ortamda öğretmen adaylarının edindikleri tecrübeler ve çevrimiçi öğrenmeye olan hazır bulunuşlukları öğretim sürecinin verimi açısından önemli bir unsur olarak karşımıza çıkmaktadır. Gelecek zamanların öğretmenleri olacak bu kesimin çevrimiçi ortamlarda gerçekleşen öğrenmeye yönelik hazır bulunuşlarının meslek hayatlarına yansımalarının olacağı da aşikârdır.

\section{Amaç}

$\mathrm{Bu}$ çalışmanın amacı öğretmen adaylarının çevrimiçi ortamda öğrenmeye yönelik hazır bulunuşluklarını tespit etmektir. Araştırmanın çalışma grubunu Türkiye' deki bir Eğitim Fakültesinde Uzaktan Eğitim yoluyla Pedagojik formasyon eğitimi almakta olan ve gönüllülük esasına göre görüşmelere katılan öğrenciler oluşturmaktadır.

\section{Yöntem}

Araştırma Modeli: Araştırma kapsamında öğretmen adaylarının çevrimiçi öğrenmeye hazır bulunuşlukları derinlemesine incelenmeye çalışılmış, böylece bu olguya ilişkin "nasıll" ve "niçin" sorularına cevap bulabilmek amaçlanmıştır. Araştırma, bütüncül tek durum deseninde gerçekleştirilmiştir. Bu desende adından da anlaşılabileceği gibi tek bir analiz birimi ve bir durum söz konusudur (Yıldırım ve Şimşek, 2006). Araştırma, var olan bir 
durumu olduğu gibi betimlemektedir. Elde edilen veriler betimsel analiz yöntemi ile analiz edilmiştir. Bu yaklaşımda veriler daha önce belirlenen temalara göre özetlenir ve yorumlanır (Yıldırım ve Şimşek, 2000).

Çalışma Grubu: Katılımcılar, 2015-2016 güz yarıyılında Yüzüncü Yıl Üniversitesi Eğitim Fakültesinde Pedagojik formasyon eğitimi almakta olan öğrencilerden oluşmaktadır. Öğrenciler görüşmelerin yapıldığı tarihte Pedagojik formasyon eğitimlerini Uzaktan Eğitim yoluyla almaktadırlar. Görüşmelere gönüllülük esasına göre katılmışlardır. Katılımcılardan yedisi kadın ikisi erkektir. Katılımcılardan üçü lisans son sınıf öğrencisidir ve ikisi Anadolu Üniversitesi Açıköğretim Fakültesi Sosyoloji bölümünde, biri Yüzüncü Y1l Üniversitesi Edebiyat Fakültesi Türk Dili ve Edebiyatı bölümünde öğrenim görmektedir. Geri kalan katılımcılardan ikisi hemşire olarak, biri ders ücreti karşılığı sınıf öğretmeni olarak, biri Aile ve Sosyal Politikalar Bakanlığına bağlı bir yetiştirme yurdunda memur olarak görev yapmaktadır. Kalan ki katılımdan biri Anadolu Üniversitesi Açıöğretim Fakültesi Sosyoloji bölümü mezunudur ve ev hanımıdır; diğeri ise Elektronik Mühendisliği mezunudur ve çalışmamaktadır.

Veri Toplama Aracı: Çalışma kapsamındaki veriler öğretmen adaylarının çevrimiçi ortamda öğrenmeye karşı hazır bulunuşluklarını belirlemeyi amaçlayan görüşme formu kapsamında sorulan sorular aracılığı ile elde edilmiştir. Görüşme formunda yer alan sorular alan yazından faydalanılarak oluşturulmuştur. Hung (2016) tarafından çevrimiçi öğrenmeye hazır bulunuşluk ile ilgili olarak dört boyut ortaya konulmuştur. $\mathrm{Bu}$ boyutlar, İletişim öz yeterliliği, Kurumsal Destek, Öğrenme öz yönlendirmesi ve Öğrenmeyi transfer öz yeterliliği şeklindedir. $\mathrm{Bu}$ çalışmada bu boyutlar göz önünde bulundurularak odak grup görüşmeleri yürütülmüştür. 
Veri Toplama Süreci: Çalışma kapsamında elde edilen veriler araştırmacı tarafından yapılan görüşmeler yoluyla üç oturumda toplanmıştır. Birinci görüşme oturumu odak grup görüşmesi şeklinde olmuştur. Bu oturum 11.02.2016 tarihinde iki katılımcı ile yürütülmüştür ve 27 dakika sürmüştür. İkinci görüşme oturumu 23.02.2016 tarihinde altı katılımcı ile yürütülmüştür. Odak grup görüşmesi şeklindeki oturum 46 dakika sürmüştür. Üçüncü oturum bireysel görüşme şeklinde oluştur ve tek katılımcıyla gerçekleştirilmiştir. 23.02.2016 tarihinde yapılmıştır ve 12 dakika sürmüştür. Odak grup görüşmeleri Yüzüncü Y1l Üniversitesi Eğitim Fakültesi Bilgisayar laboratuvarında, bireysel görüşme ise araştırmacının kendi ofisinde yapılmıştır. Görüşmeler katılımcıların da onayı alındıktan sonra ses kaydı olarak depolanmıştır.

Verilerin Analizi: Elde edilen veriler nitel veri analizi yöntemleri ile analiz edilip sunulmuştur. Elde edilen veriler üzerinde betimsel analiz yapılmıştır.

Çalışmanın Geçerliliği ve Güvenirliği: Araştırmalarda geçerlik güvenirliği belirleyen önemli bir etkendir. Dolayısıyla Nitel araştırmalarda geçerlik güvenirliğe göre önceliklidir ve daha önemlidir (Yıldırım ve Şimşek, 2000). Bu çalışmada geçerliliği sağlayabilmek için çevrimiçi öğrenmeye hazır bulunuşluk ile ilgili alanyazın incelenmiş ve Hung (2016) tarafindan ortaya konan dört boyutlu model referans alınarak düzenlenen görüşme formuna göre görüşmeler yürütülmüştür. Çalışma bulguları sunulurken doğrudan katılımcı ifadelerine yer verilmiştir.

Nitel araştırmalarda güvenirlik, araştırmacının çalışma sürecinde kullandıkları stratejileri belirgin hale getirerek sağlanabilir. Böylelikle diğer araştırmacıların bu stratejileri kullanabilmelerine olanak sağlanmış olur (Yıldırım ve Şimşek, 2000). Bu çalışmada dış güvenirliği sağlamak için araştırma süreci açık şekilde ortaya konulmaya çalışılmıştır. 
Katılımcı özellikleri açık şekilde tanımlanmıştır. Veri toplama ve bunların analizi süreci açıklanmıştır. İç güvenirlik için ise elde edilen veriler mümkün olduğunca betimsel yaklaşımla sunulmuş, yorum katılmamıştır. Çalışmaya dayanak olan kavramsal çerçeve açıklanmıştır.

\section{Bulgular ve Yorum}

İletişim Öz Yeterliliğine İlişkin Bulgular: Öğretmen adaylarına, çevrimiçi öğrenme ortamındaki iletişim süreçleri hakkında fikir sahibi olmak amacıyla "Çevrimiçi öğrenme ortamındaki iletişim sürecinizden bahsedebilir misiniz?” sorusu yöneltilmiştir. Öğretmen adaylarının görüșleri Tablo1’ de verilmiștir.

Tablo 1. Öğretmen Adaylarının Çevrimiçi Ortamdaki Illetişim Süreçleri Hakkındaki Görüşleri

\begin{tabular}{lc}
\hline \multicolumn{1}{c}{ Katılımcı görüşleri } & Frekans \\
\hline Öğretim elemanı ve sosyal yalıtılmışlık & 5 \\
Uzaktan eğitimin sağladığı kolaylıklar & 4 \\
Öğrenme Yönetim sistemi ve iletişim süreci & 4 \\
Fırsat eşitliği & 3 \\
Sınıf ortamında gibi hissediyoruz & 2 \\
\hline
\end{tabular}

Tablo 1 incelendiğinde öğrencilerin en çok çevrimiçi ortamda ders anlatan öğretim elemanı ile ilgili görüş bildirdikleri görülür. “Acaba boşluğa mı anlatıyorum, kimse karşımda yok". "Yani boşluğa anlatıyor gibi mi, ne hissediyorlar biz de onu çok merak ediyoruz" gibi ifadelerle bir iletişim süreci olan öğretim sürecinde öğretim elemanlarının öğrencilerle yeterince etkili iletişim kuramadıkları ve bunun sonucunda sosyal olarak yalıtılmış hissedip hissetmeme durumlarını merak ettiklerini ifade etmişlerdir. Bunun yanı sıra "Biz çok rahattık da öğretim elemanları rahat mıydı karşıda bize anlatırken. Onlar bir de ekrana bakıyorlar. Biz onu görüyoruz. Hareket ederken konuşurken onlar rahat mıydı ben onu çok merak ediyorum”. “Öğretim elemanının o anki psikolojisini anlayabiliyorduk, rahatsızlık hissederek elini yüzüne götürerek o hareketleriyle rahat bir şekilde dersi anlatamayan öğretim elemanı vardı”. 
"Dersine hakim öğretim elemanı bizi ekrana bağlayabiliyordu. Konusuna ve dersine hakim olmayan öğretim elemanı, kahvemi alıp öbür odada içiyordum, açık bırakıyordum” gibi ifadelerle de öğrencilerin öğretim elemanlarını görebildiklerini fakat öğretim elemanlarının öğrencileri takip edemediklerini ifade etmişlerdir.

Katılımcılardan dördü çevrimiçi öğrenme ortamına uzaktan erişimin sağladığ kolaylıklardan bahsetmiştir. Bu öğrenciler "Zaten çalışıyorum, ev idare ediyorum... Yolda harcayacağım zamanı ben derse çalışarak değerlendirebiliyordum”, "Hem bu konuda eğitimimi tamamlıyorum hem de iş hayatıma devam ediyorum”, "Zamandan kazanılıyor. Ben ev hanımıyım. Hem çocuklar hem ev. Zamandan kazanıyordum, eğitime vakit ayırabiliyordum”, "Benim için en güzel avantajı çalıştığım için zaman kaybımı engelliyordu" gibi ifadelerle duyuşsal olarak bu tarz öğretimi benimsediklerini ifade etmişlerdir.

Dört öğrenci ise "Bilgisayar sistemini de çoğumuz bildiğimiz için, hani sistemi birbirimizle yardımlaşarak, arkadaşlar yeni bir şey buldukları zaman hemen böyle böyle yapın diye sistemi de böylelikle kısa zamanda çözdük hepimiz.”, “İletişim kurarken hiç bir sıkıntı yaşamadım. Zaten kendim bilgisayar kullanmayı çok iyi biliyorum.”, “İlk başta zorlandım. Çok fazla pratik vaktim olmuyordu oturup onu kurcalamaya. Çocuklarımdan yardım aldım. Gayet iyi oldu daha sonra.", "bilgisayarı bulamasak bile cep telefonumuzdan bile girebildiğimiz için derse telefonla da girebiliyorduk.” gibi ifadelerle çevrimiçi öğrenmenin gerçekleștiği Öğrenme Yönetim Sistemini rahatlıkla kullanabilme durumlarını yansıtmışlardır.

Üç öğrenci ise çevrimiçi ortam aracılığı ile öğretim elemanlarına rahatlıkla ulaşabilme durumlarını "öğretim elemanının yüz ifadelerinden benim sorduğum soruya cevap verebileceğini anlayabiliyordum. Fırsat eşitliği açısından da benim için ideal bir seçenekti.”, 
"Bu süreçte öğretim elemanlarıyla birebir iletişime geçebiliyorduk. Bir tersleme ya da bir şey yoktu. Sağ olsunlar cevap veriyorlardı", "bilgisayar ortamı sosyal hayattan daha aktarım konusunda rahat oluyor insanlar. Sonuçta görünmediği için istediğini sorabiliyor saçma da olsa. yani o açıdan avantajlı hani olmaması gereken bir şey belki ama daha rahat ediyorduk" gibi ifadelerle yansıtmışlardır.

İki öğrenci ise "bence normal bir sınıf ortamını gibi, gayet verimli, gayet verimli olduğunu düşünüyorum” ve “öğretim elemanının bilgilerinden çok rahatlıkla yararlanabiliyoruz. Arkadaşlarımızı görmesek bile bir sınıf ortamında olduğumuzun farkında oluyoruz" ifadeleri ile yüz yüze sınıf ortamındakine benzer rahatlıkta ders işlediklerini ifade etmişlerdir.

Öğretmen adaylarının, çevrimiçi ortamda yapılan tartışmalar esnasında soru sorarken ve sorulan sorulara cevap verirken nasıl hissettiğini; eşzamanlı yazışma ortamını rahat kullanıp kullanamadıklarını; bu ortamda duygularını rahat ifade edip edemediklerini belirleyebilmek için "Soru sorarken veya sorulan soruları cevaplandırırken rahat hissediyor muydunuz", "Eşzamanlı yazışma ortamını rahatlıkla kullanıyor muydunuz?”, "Çevrimiçi ortamda duygularınızı rahatça ifade edebiliyor muydunuz?" şeklinde sorular yöneltilmiştir. Katılımcıların görüşleri Tablo2' de sunulmuştur.

Tablo 2. Öğretmen Adaylarının Çevrimiçi Ortamda Yapılan Tartışmalar Esnasında Nasıl Hissettikleri Hakkındaki Görüşleri

\begin{tabular}{lc}
\multicolumn{1}{c}{ Katılımcı görüşleri } & Frekans \\
\hline Eşzamanlı yazışma ile olan soru-cevap yaklaşımı ve buna alışma süreci & 4 \\
Eşzamanlı yazışmayı rahat kullanmaya yönelik maddeler & 3 \\
Diğer öğrencilerle kurulan sıcak iletişim & 2 \\
Uzaktan eğitim ihtiyacı ve olumlu tutum & 2 \\
Yüzyüze iletişime oranla kendini daha kolay ifade edebilme & 2 \\
\hline
\end{tabular}

Tablo 2' ye bakıldığında dört öğrencinin 'İlk haftalarda oldu daha sonra, bir nasıl diyeyim, alıştık daha sonra gayet de rahat oldu diye düşünüyorum.”, "Ortamın daha özverili 
sağlıklı olduğunu yansıttığı için daha rahatlıkla sorularımızı soruyorduk ve bunlara çok rahatlıkla cevaplar alıyorduk.”, "Başta zorlandım ama çocuklarım sağ olsun yardımcı oldular. Çözdüm yani. İlk bir iki haftada zorlandım, daha sonra sıkıntı yoktu.”, "Gayet iyiydi güzeldi.”, “ilk soru belki uzun sorulduğu için anlaşılamayabiliyor gibi ama daha sonradan öğretim elemanları zaten anlıyorlar bizim sormak istediğimizi ve düzeltiyorlar.” gibi ifadeler kullanarak eşzamanlı ortamda gerçekleştirdikleri soru-cevap sürecine zamanla alıştıkları ve verimli şekilde kullanabildiklerini ifade etmişlerdir. Üç öğrenci ise eşzamanlı yazışma ortamını rahatlıkla ve sıkıntı çekmeden kullanabildiklerini söylemişlerdir.

İki katılımcı diğer öğrencilerle sıcak bir iletişim kurabildiklerini "akıllı telefonumuz aracılığıyla iletişim kurduğumuz bir grubumuz vardı bizim. Gerçekten çok sıcak bir ortam, rahattı yani hiç bir sıkıntımız yoktu" ve "fark ettim ortam sanki biraz daha sıcak oldu. Üniversitede ben şunu görmüştüm. bir gruplaşma oluyordu. Burada kimse birbirini tanımıyor. Her kes cana yakın, bir anda daha sıcak bir ortam oldu.” İfadeleriyle dile getirmişlerdir.

İki öğrenci ise " $\mathrm{Bu}$ şansı iyi değerlendirebilirsek çok daha farklı kaynaklardan çok daha farklı kişilerden, mesela sadece bir öğretim elemanına bağımlı kalmıyoruz. Çok farklı kaynaklardan, çok farklı kişilerden fikirlerini alıyoruz." ve "ilk dönem dersleri materyalden, materyal gerektirmeyen derslerdi bu yüzden sıkıntı duymadım yani uzaktan eğitimde" gibi ifadelerle çevrimiçi ortama uzaktan bağlanarak gerçekleştirdikleri öğrenme sürecine olan ihtiyaçlarını ve olumlu tutumlarını yansıtmışlardır.

Bu konuyla ilgili olarak iki öğrenci ise "belki yüz yüze eğitimde olsaydım kendimi kasabilirdim" ve "belki sınıf ortamında olsak açık yüreklilikle belki söyleyemeyeceğimiz şeyleri bile orada yazabiliyorduk" diyerek yüz yüze iletişime oranla kendilerini daha rahat ifade edebildiklerini belirtmişlerdir. 
Kurumsal Desteğe İlişkin Bulgular: Katılımcıların öğrenme sürecinde, dersin öğretim elemanları ve dersi alan diğer arkadaşları ile olan iletişim süreci hakkında bilgi alabilmek amacıyla "Çevrimiçi öğrenme ortamındaki eğitim sürecinde dersin öğretim elemanı ve diğer arkadaşlarınızla olan iletişiminizden bahsedebilir misiniz?” sorusu yöneltilmiştir. Öğretmen adaylarının görüşleri Tablo 3' dedir.

Tablo 3. Katılımcıların dersin öğretim elemanları ve diğer arkadaşları ile olan iletişim süreçleri hakkındaki düşünceleri

\begin{tabular}{ccc}
\hline & \multicolumn{1}{c}{ Katılımcı görüşleri } & Frekans \\
\hline Öğretim elemanlarıyla olan iletişim ve zamanı etkili kullanma & 9 \\
$\checkmark$ & Öğretim elemanının pedagojik açıdan yeterliliği & 2 \\
$\checkmark$ & Öğretim elemanının pedagojik açıdan yetersizliği & 2 \\
$\checkmark$ & Öğretim elemanının zamanı etkili kullanması & 2 \\
$\checkmark$ & Öğretim elemanını ile iletişim kurarken rahat hissetme & 2 \\
$\checkmark$ & Ŏğretim elemanına rahat ulaşabilme & 1 \\
\hline Akran iletişimi & 2
\end{tabular}

Tablo 3 incelendiğinde, "Bazı öğretim elemanlarımızla tam bir sınıf ortamı oluşuyor. Birbirimize soru sorabiliyoruz. Bazı öğretim elemanları kontrol ediyorlar arkadaşın dediği gibi hatta anladınız mı veya bir sıkıntınız var mı? Farklı kaynaklardan bahsedebiliyorlar bize yardımc1 oluyorlar. Ben bundan memnunum." "Öğretim elemanları öğrenciyi nasıl ekrana bağlaması gerektiğini bilebilmeli. Ben pür dikkat X öğretim elemanıyla Y öğretim elemanını dinliyordum, Z öğretim elemanını dinliyordum.” ifadeleriyle iki katılımcı öğretim elemanlarının pedagojik açıdan yeterliliklerini vurgulamışlardır. Buna karşın "Bazı öğretim elemanları da sadece slayta bağlı kalıyorlar, anlatıp bitiriyorlar. Bundan benim şikâyetim bundan dolayı" ve "Bence dersi veren öğretim elemanlarının uzaktan eğitim için önceden eğitilmesi lazım. Bazı öğretim elemanlarını dinleme isteği yoktu. Dümdüz okunuyor, okunuyor... dönüt al yok öğretim elemanında düz okuma var” ifadeleri ile de bazı öğretim elemanlarının pedagojik açıdan yetersizliği vurgulanmıştır. 
İki katılımcı "Sistemden çıktıktan sonra ders bitiyor. O yüzden öğretim elemanı zamanını değerli olarak kullanıyor. Orada sorular sorulur ve biter. Hani gereksiz uzunluk yoktu." ve "Hayat hikâyelerini anlatmıyorlar. Onu çok gördük öğretim elemanları ders kaynadığı zaman genelde öğretim elemanlarının ailevi sorunlarını ailevi ilişkilerini onların geçirdikleri aşamaları duyuyorduk ama burada öyle bir şey yoktu.” ifadeleri ile öğretim elemanlarının zamanı etkili kullanma durumlarından bahsetmişlerdir. Öğretim elemanları ile iletişim konusunda son olarak iki katılımc1 "Yüz yüze eğitim ortamında bazen soru sormak istemiyorsun. Diyorsun ki hani cevap vermeyebilir. Ama uzaktan eğitimde böyle bir şey yok. Öğretim elemanı cevap veriyor." ve "Kendimizi daha iyi ifade edebiliyorduk diyebilirim. Çünkü üniversitede öğretim elemanları bazen daha çalışkan olanlara daha iyi bakarlar ya. Burada böyle bir şey yok. Öğretim elemanı kimin kim olduğunu bilmiyor. Herkesin sorusuna önem verebiliyor.” ifadeleri ile öğretim elemanı ile rahat iletişim kurabilme durumunu ortaya koymuş, bir kişi ise "O anda ders bitti diye şey yoktu, zaten öğretim elemanlarına ulaşabilmemiz için her türlü imkânı sağlıyorlardı. Adreslerini verdiler, iletişim bilgileri, emailleri her şeyleri vardı yani. Öğretim elemanlarına ulaşma konusunda bir sıkıntımız yoktu bizim" ifadesi ile öğretim elemanlarına rahat ulaşabilme durumunu vurgulamıştır.

Akran iletişimi konusunda ise bir öğrenci “Arkadaşlarla what's up grubumuz var. Arkadaşlarla bir sorunumuz yok, oradan not paylaşımı yapabiliyoruz, bilgi alış verişi yapabiliyoruz. Gayet iyi oluyor. Belki öğretim elemanlarından daha da verimli olabiliyordur” ifadesi ile çok iyi iletişim kurabildiklerini bir öğrenci ise "arkadaşlarımızla bir iletişim yok açıkçası. Her kes birbirinden uzak. Sadece benim için değil. Geri kalanı için de böyle olduğunu düşünüyorum” ifadesi ile tam tersi bir durumu ifade etmiştir. 
Çevrimiçi ortamda gerçekleşen dersler kapsamındaki kurumsal yapı hakkında ayrıntılı bilgi alabilmek için “Dersin öğretim elemanı sizin öğrencilik performansınızı nasıl görüyor?”, "Bu ders sonrası elde ettiğiniz kazanımları iş hayatında kullanma durumunuzla ilişkin olarak dersin öğretim elemanı sizce ne düşünüyor?”, "Dersi alan diğer arkadaşlarınız sizin öğrencilik performansınızı nasıl görüyor", "Sağlanan teknik altyapı konusunda ne düşünüyorsunuz" soruları yöneltilmiştir. İlgili sorular hakkındaki öğrenci görüşleri Tablo 4' te yer almaktadır.

Tablo 4. Çevrimiçi dersler kapsamındaki kurumsal yapı hakkındaki öğrenci görüşleri

\begin{tabular}{lc}
\hline \multicolumn{1}{c}{ Katılımc görüşleri } & Frekans \\
\hline Öğretim elemanının öğrencilik performanslarını gözlemleyememesi & 4 \\
Öğretim elemanlarını öğrencilik performanslarını iyi bulması & 2 \\
Sürecin verimliliği ve öğrenilenlerin meslek hayatına yansıtılabilir olması & 2 \\
Eşzamanlı yazışma ortamındaki aktifliğimize göre karar verebilirler & 3 \\
Teknik altyapıya ilişkin olumsuz ifadeler & 3 \\
Teknik altyapının yeterli olduğuna ilişkin ifadeler & 4 \\
Öğrenme Yönetim Sistemindeki Arşiv bölümü & 2 \\
\hline
\end{tabular}

Tablo 4' te özet şekilde sunulan veriler biraz açılacak olursa, bazı öğrenciler “çevrimiçi olduğu için öğretim elemanının bizim performansımızı tam olarak ölçmesi herhalde mümkün olmuyor”, "İyiydi ama öğretim elemanı bizi nasıl değerlendirir o kadarını ben bilemem. Çünkü sonuçta bizi görmüyor”, “Görüntü akılda kalabilir ama ismi pek akılda tutamayabilirler. O yüzden öğrenciler arasında bir ayırım yapabileceklerini düşünemiyorum uzaktan eğitimde" gibi ifadelerle öğretim elemanlarının öğrencilerin performanslarını gözlemleyemediklerini ifade etmişlerdir. İki öğrenci ise "Evet bizden memnundu çünkü soru sorduğu zaman biz soruların cevabını verip sonra da tartışabiliyorduk" ve "Yani şöyle biz orada çalışacağımız kaynakların paylaşımını da yaptığımız için sadece uzaktan eğitimle aldığımız o dersle kalmayıp bunu kendimiz de ne katabilirizi düşünüp de paylaştığımız için bu anlamda onlar da bizi yeterli görüyorlardır diye düşünüyorum" ifadeleri ile öğrencilik performanslarının öğretim elemanları tarafından iyi görüldüğü düşüncesini yansıtmışlardır. 
İki öğrenci "Bence öğretim elemanlarımız bizim bunu ileride kullanabileceğimizi düşünüyorlardır", "Elbette anlattıkları verimli oluyor yani iş hayatımızda da, öğretmenlik hayatımızda da ileride olursa kullanırız diye düşünüyorum. Verimli olur, her ne kadar örgün eğitim kadar olmasa da yine de olur.” ifadeleri ile öğretim elemanlarının öğrendikleri bilgileri iş hayatına yansıtabileceklerini düşündüklerini yansıtmışlardır.

Üç öğrenci ise öğrencilerin birbirlerinin öğrencilik performanslarını eşzamanlı tartışma ortamındaki aktiflik derecesine göre değerlendirebileceklerini "Ne kadar çok aktifsek o kadar iyi olduğumuz düşünülüyordur.”, “Kendi grubumuz için konuşayım. Onlar da benzer şeyler düşünüyorlardır. Çünkü kendi grubumuzla whatsApp grubundan sürekli sohbet edip ne yapabiliriz. Neye çalışalım, neyi alalım gibi düşündüğümüz için onlar da böyle düşünüyorlardır diye düşünüyorum.”, "Birbirimizi tanıyor gibi olduk, kaynaştık whatsApp grubu ile iyiydi yani.” gibi ifadelerle belirtmişlerdir.

"Şu anda bizin kendi bağlandığımız sistemin teknik alt yapısının iyi olmadığını düşünüyorum... ve sorduğumuz zaman da karşımızda bir muhatap bulamıyoruz”, "Öğretim elemanının sesi kesik kesik geliyor. Bize problem sizden, sizin bilgisayarınızdan, başka bir vericiden bağlanın diye uyarılar geliyor”, “ya ses gidiyor ya da görüntü gidiyor. Bir de belli bir zaman aralığı olduğu için o derste yeteri verim de alamayabiliyorsunuz bazen. Bazen iyi de olabiliyor tabi ki... Bazen iletişim problemleri yaşıyoruz”, “Öğretim elemanının sesi bize gelmediği için. Bizim üç dersimiz gitti”, “. Teknik anlamda bazen sıkıntılar yaşadık ses ve görüntü konularında” gibi ifadelerle üç öğrenci teknik altyapıya ilişkin olarak olumsuz ifadeler kullanmışlardır. Buna karşın dört öğrenci ise "ufak tefek sıkıntılar yaşansa da genel anlamda teknik altyapı anlamında çok da sıkıntı yaşamadık", "Teknik altyapı... İlk yılı mıydı uzaktan eğitimin? Eğer öyleyse ona göre mükemmele yakın bir şeydi. Çünkü bilgisayara 
herhangi bir program da yüklemedik biz. Telefondan da çok rahat bir şekilde bağlanabiliyorduk. O yüzden iyiydi. Sıkıntı yoktu”, "derslere bağlanma konusunda sıkıntı yaşamadım. Sınavlarımı eksiksiz şekilde tamamladım. Teknik donanım olarak bir eksikliğini görmedim”, “bazen ses gelmiyordu, görüntü gelmiyordu, bu tür aksaklıklar oluyordu teknik hata olarak. O da kısmi olarak gideriliyordu. 5-10 dakika gecikmeli giriliyordu. Ama derslerimiz yetişiyordu, her kes alabildiğini alıyordu öğretim elemanlarımız gerekli zamanı kullanıyordu" gibi ifadelerle teknik alt yapının yeterli olduğunu düşündüklerini belirtmişlerdir.

İki öğrenci “Arşiv olayı vardı o çok etkiliydi. Örgün eğitimde öyle bir şansımız yoktu. Aynı şeyleri öğretim elemanının yorumlarıyla slaytlarla beraber tekrar dinlediğimiz için bu çok önemli" ve "Mesela öğretim elemanı bir yazı yazmış, kendisi anlatıyor ama hani sen o yazıdan çok şey çıkarmayabilirsin ama tekrar arkadaşımın dediği gibi arşivi açtığın zaman tekrar tekrar o yazılan daha iyi anlaşılıyordu" ifadeleri ile çevrimiçi öğrenme ortamının sağladığı arşiv bölümü sayesinde öğrenmelerini pekiştirebildiklerini ifade etmişlerdir.

\section{Öğrenme Öz Yönlendirmesine İlişkin Bulgular: Öğretmen adaylarının çevrimiçi} öğrenme sürecindeki bireysel öğrenmeleri hakkında bilgi edinmek amacıyla "Çevrimiçi öğrenme sürecinde kendi öğrenmenizi yönetme noktasında kendinizi nasıl buluyorsunuz?" sorusuna verdikleri yanıtlar Tablo 5' de sunulmuştur.

Tablo 5. Öğrencilerin kendi çalışmalarını yönlendirme durumlarına ilişkin görüşleri

\begin{tabular}{lc}
\hline \multicolumn{1}{c}{ Katılımcı görüşleri } & Frekans \\
\hline Bireysel gelişim için çalışma & 3 \\
Ders öğretim elemanının etkisi ile çalışma & 2 \\
Sınav için çalışma & 1 \\
Planlı bir eğitimin etkisiyle düzene girme & 1 \\
\hline
\end{tabular}

Tablo 5' e bakıldığında 'Kendim de ekstra çalışmalar yapıyorum konuyla ilgili ya da çok önemsediğim bir konu varsa bunun ileride benim yararlı olduğunu düşündüğüm bir konu 
varsa onu özellikle araştırıyorum”, “de sadece sınavı geçmek için değil benim hayatıma ne katacak onun için çaba gösteriyorum. Dersin dışında farklı kaynaklardan yararlanıyorum” gibi ifadelerle üç öğrenci bireysel gelişimleri için çalıştıklarını ifade etmiştir. İki öğrenci ise bazı öğretim elemanlarının etkili ders işlemesinin sonucu olarak çalıştıklarını "Dersine hâkim öğretim elemanını daha isteyerek severek dinliyordum. Not tutuyordum. Hâkim olmayan öğretim elemanını dinlemiyordum” ve "Ders etkili ve öğretim elemanıyla etkileşim halinde geçiyorsa o dersi dinleyip soruları cevaplayalım doğru mu yaptık, yanlış mı yaptık bu konuda oluyordu. Ama dersi dinlemesini sevmediğim öğretim elemanının dersini slaytlardan çalışıyordum" ifadeleri ile yansıtmışlardır. Birer kişi ise "Ders çalışma konusunda tabi bir sınav var. Belli bir tarih konulmuş. Ona göre kendini ayarlıyordum" ve "Sistemin verdiği önceden hatırlatmalarla günümüzü ona göre ayarlıyorduk, planlarımızı, işimizi ya da herhangi bir şeyimizi. Hani o gün ders var o saatte ona göre ayarlıyorduk" ifadeleri ile sınava odaklı ve planlı bir eğitim süreci olmasının etkisiyle çalıştıklarını söylemişlerdir.

Öğretmen adaylarına çalışma planlarını yapabilme, zamanı etkili kullanma ve ders sürecinde diğer çevrimiçi araçları kullanabilme durumuna ilişkin olarak "Kendi çalışma planınızı düzenleyebiliyor musunuz?", “Zamanı iyi yönetebiliyor musunuz?” ve "Diğer çevrimiçi aktiviteler (mesajlaşma, internette sörf) sizi meşgul ediyor mu?” soruları yöneltilmiştir. Katılımcıların görüşlerine Tablo 6' da yer verilmiştir.

Tablo 6. Öğretmen adaylarının çalışma planları, zaman kullanımı ve çevrimiçi araçlarla meşgul olma durumlarına ilişkin görüşleri

\begin{tabular}{lc}
\hline \multicolumn{1}{c}{ Katılımcı görüş̧leri } & Frekans \\
\hline Ders konusu hakkında araştırmalar yapma & 2 \\
Ders dışı aktivite yapmama & 4 \\
Öğretim elemanının tavrına bağlı olarak başka şeylere dalma & 2 \\
\hline
\end{tabular}

Tablo 6 incelendiğinde iki öğrencinin “ders dışı bir şey değil de daha çok kendi grubumuzla ders içi olan sohbeti bir anlamda değerlendiriyoruz. Yoksa hani çok da dersin 
ötesinde bir şeye takılmıyorum" ve "Dersi dinlerken arkadaşların yazışmalarına da baktığımız zaman bazen kayıyorduk. Yazışmalara kayıyorduk. Ki bu öğretim elemanlarında da oluyordu. Yazışmalara kayabiliyorlardı. Ama oradan arkadaşlarımızın verdiği örnekler. Öğretim elemanının anlattığı, öğretim elemanı anlatıyor neden diye sorduğunda anında dönüt almamız falan bizim avantajımıza oluyordu ve iletişimimiz gayet de iyi oluyordu bu şekilde" ifadeleriyle ders konusu hakkında araştırmalar yaptıklarını yansıtmışlardır. Dört öğrenci ise, "Ben kendim ders esnasında bunları (mesajlaşma, internette sörf) yapmıyorum”, "başka bir şeye açıkçası benim gözüm dalmıyordu", "Yok çok meşgul etmiyordu (diğer çevrimiçi aktiviteler)", "Benim yok (Diğer çevrimiçi aktivitelere takılma gibi)" ifadelerle çevrimiçi dersler esnasında ders dışı aktivite yapmadıklarını ifade etmişlerdir. İki öğrenci ise “öğretim elemanı ne kadar iyiyse bizi çekebiliyordu. Ama yok öğretim elemanı dersi anlatamıyorsa ben dersi dinleyemiyordum başka şeylere ister istemez dalabiliyordum" ve "Yani bence işte bu öğretimi veren kişiye bağlı bazı derslerde bu gayet iyi (zaman kullanımı) bazılarında da iyi değil açıkçası. Öğretim elemanına bağlı.” ifadeleri ile öğretim elemanının tavrına bağlı olarak başka şeylere daldıklarını ifade etmişlerdir.

Öğrenmeyi Transfer Öz Yeterliliğine İlişkin Bulgular: Öğretmen adaylarının çevrimiçi öğrenme ortamında edindikleri bilgileri meslek hayatlarına transfer edebilme durumlarını tespit edebilmek için "Çevrimiçi ortamda gerçekleşen öğrenmelerinizi meslek hayatınıza transfer etme noktasında neler düşünüyorsunuz?” sorusu yöneltilmiştir. Katılımcıların görüşleri Tablo 7’ de özetlenmiştir.

Tablo 7. Öğretmen adaylarının çevrimiçi ortam öğrenmelerini meslek hayatına transfer edebilme konusundaki düşünceleri

\begin{tabular}{lc}
\hline \multicolumn{1}{c}{ Katılımcı görüşleri } & Frekans \\
\hline Meslek hayatında kullanabilirim & 3 \\
Meslek hayatı için biraz daha yol kat etmem lazım & 2 \\
\hline
\end{tabular}


Katılımcıların Tablo 7' de özetlenen duruma ilişkin olarak üç tanesinin edindikleri bilgileri meslek hayatlarına transfer edebileceklerini "aldığımız eğitimi uygulayabileceğimizi düşünüyorum”, “ben kullanabileceğimi düşünüyorum”, "ilk baştakine göre ben de tecrübesizdim ama şimdi iyi olduğumu düşünüyorum” ifadeleri ile yansıtmışlardır. İki öğrenci ise kendilerini tam olarak yeterli hissetmemeleri durumunu "Şu an için çok da yeterli olmayabilir" ve "Şu anda yeterli düzeyde değilim bunu görüyorum kendimde" ifadeleri ile yansitmışlardır.

Katılımcıların çevrimiçi ortamdaki öğrenmelerini transfer edebilme durumları hakkında ayrıntılı bilgiler edebilmek için “Öğretmenlik mesleği konusunda ilerlemeler kaydettiniz mi?”, “Öğrendiklerinizi meslek hayatınızda kullanabilecek durumda mısınız?”, “Meslektaşlarınızla bilgi paylaşımı yapabilecek durumda mısınız?”, "Bu dersi aldıktan sonra kendinize olan mesleki beklentiniz arttı mı?” soruları sorulmuştur. Öğretmen adaylarının bu konular hakkındaki düşünceleri Tablo8' de sunulmuştur.

Tablo 8. Katılımcıların Çevrimiçi ortamdaki öğrenmeleri meslek hayatına transfer edebilme konusundaki diğer düşünceleri

\begin{tabular}{lc}
\hline \multicolumn{1}{c}{ Katılımcı görüşleri } & Frekans \\
\hline Meslek bilgisi olarak ilerleme kaydedildiğine ilişkin ifadeler & 4 \\
Öğrendiklerimi meslek hayatımda kullanma konusunda emin değilim & 2 \\
Meslektaşlara yol gösterebilme & 2 \\
Meslektaşlara yol gösterebilme noktasında yetersizlik & 1 \\
Öğretmenlik mesleğine yönelik mesleki beklenti & 4 \\
\hline
\end{tabular}

Öğrencilerin çevrimiçi ortam öğrenmelerini mesleki hayatlarına transfer etme noktasındaki ayrıntılandırılmış düşüncelerinin yer aldığı Tablo 8' e bakıldığında dört öğrencinin "ilk bilgilerinizle eğitim aldıktan sonraki bilgileriniz değişiyor daha çok şey katıyorsunuz", "Evet tabi ki düşünüyorum (ilerleme kaydettiğimi)", "biraz daha yeterli buluyorum ama teorik olarak", "Hangi tekniği uygularsam daha iyi olabileceğini biliyorum”, “Tabi ki düşünüyorum” ifadeleri ile ilk zamanlara göre yol kat ettikleri anlaşılmaktadır. 
İki öğrenci ise öğrendiklerini meslek hayatında kullanma noktasında tam emin olamadıklarını “... Ama yeterli miyim, tabi ki değilim ...” ve “... Ama pratiğini bilmiyoruz, nasıl olur ..." sözcükleri ile yansıtmışlardır.

İki öğrenci “öğretmen olursam arkadaşlarımla da paylaşabileceğim çok güzel şeyler var diye de düşünüyorum" ve "Kendi arkadaşlarım arasında birbirimize yol gösterebiliyoruz" ifadeleri ile mesleki konularda diğer insanlara yol gösterebilme noktasındaki yeterliliklerini yansıtmıştır. Bir öğrenci ise “öyle bir yeterliliğim olduğunu düşünmüyorum” ifadesi ile bu durumun tam tersini yansıtmıştır.

Dört öğrenci “Öncesine göre arttı tabi. Bilmediğimiz bir sürü şey vardı ve şu anda bir sürü şey biliyoruz. O bilmediklerimiz üzerine bir sürü bildiğimiz şeyi ekledik ve daha verimli olacağını düşünüyorum, eğer öğretmen olabilirsek ya da öyle bir şansımız olabilirse. Bu bilgilerimizi de üstüne katarak bayağı şey yapabileceğimizi düşünüyorum”, "kendimle ilgili beklentim arttı. Bunu pratik anlamda da tamamlamak istiyorum ve orada da kendimi görmek istiyorum”, “daha çok çalışmam gerektiğini düşünüyorum. Eğitim derslerini açıkçası bu kadar çok önemsemiyordum. Daha çok yoğunlaşmam gerektiğini anladım”, "bu mesleğe daha ciddi baktım açıkçası” ifadeleri ile çevrimiçi öğrenme kapsamında öğrendikleri ile kendilerine olan mesleki beklentilerinin artığı durumunu yansıtmışlardır.

Nitel Verilerin Sayısallaştırılmasına İlişkin Bulgular: Nitel araştırmalarda araştırılan olay, olgu ya da durumun yapısına özgü bir araştırma süreci söz konusudur (Yıldırım ve Şimşek, 2006). Öğretmen adaylarının çevrimiçi ortamda öğrenmeye hazır bulunuşluklarına ilişkin verdikleri yanıtlar aşağıdaki tabloda olumlu, nötr ve olumsuz şekilde kategorize edilerek sunulmuştur. 
Tablo 9. Katılımcıların Çevrimiçi ortamda öğrenmeye hazır bulunuşlukları noktasındaki olumlu, nötr ve olumsuz düşünceleri

\begin{tabular}{|c|c|c|c|}
\hline & & OLUMLU DURUMLAR & Frekans \\
\hline 1 & & - Çevrimiçi öğrenme ortamına uzaktan erişebilmeye yönelik olumlu tutum & 4 \\
\hline 2 & & - Öğrenme Yönetim Sistemini rahatlıkla kullanabilme & 4 \\
\hline 3 & & - Öğretim elemanlarına rahatlıkla ulaşabilme & 3 \\
\hline 4 & & - Sınıf ortamındakine benzer rahatlıkta ders işleme & 2 \\
\hline 5 & & - Soru-cevap sürecini verimli kullanma & 4 \\
\hline 6 & & - Eşzamanlı yazışma ortamını rahatlıkla kullanma & 3 \\
\hline 7 & & - Diğer öğrencilerle kurulan sıcak iletişim & 2 \\
\hline 8 & & - Çevrimiçi ortama uzaktan bağlanma ihtiyacı & 2 \\
\hline 9 & & - Yüz yüze iletişime oranla kendilerini daha rahat ifade edebilme & 2 \\
\hline 10 & & - Öğretim elemanlarını pedagojik açıdan yeterli görme & 2 \\
\hline 11 & & - Öğretim elemanlarını zamanı etkili kullanması & 2 \\
\hline 12 & & - Öğretim elemanı ile rahat iletişim kurabilme & 2 \\
\hline 13 & & - Öğretim elemanlarına rahat ulaşabilme & 1 \\
\hline 14 & & - Diğer öğrencilerle çok iyi iletişim kurabilme & 1 \\
\hline 15 & & - Öğrencilik performanslarının öğretim elemanları tarafından iyi görülmesi & 2 \\
\hline 16 & & - Öğretim elemanlarına göre öğrenilenler iş hayatına yansıtılabilir & 2 \\
\hline 17 & & - Teknik altyapının yeterli olması & 4 \\
\hline 18 & & - Çevrimiçi ortamdaki arşiv bölümü sayesinde öğrenmelerin pekiştirilebilmesi & 2 \\
\hline 19 & & - Bireysel gelişim için çalışma & 3 \\
\hline 20 & & - Bazı öğretim elemanlarının etkili ders işlemesinin sonucu olarak motive olma & 2 \\
\hline 21 & & - Ders konusu hakkında araştırmalar yapma & 2 \\
\hline 22 & & - Çevrimiçi dersler esnasında ders dışı aktivitelerle ilgilenmeme & 4 \\
\hline 23 & & - Edinilen bilgilerin meslek hayatlarına transfer edilebilmesi & 3 \\
\hline 24 & & - Öğretmenlik meslek bilgisi açısından ilk zamanlara göre yol kat etme & 4 \\
\hline 25 & & - Mesleki konularda diğer insanlara yol gösterebilme & 2 \\
\hline 26 & & - Kendilerine olan mesleki beklentilerinin artması & 4 \\
\hline & & Toplam: & 68 \\
\hline \multicolumn{4}{|c|}{ NÖTR DURUMLAR } \\
\hline 1 & ? & $\begin{array}{l}\text { - Öğrencilerin birbirlerinin performanslarını eşzamanlı tartışma ortamındaki aktiflik } \\
\text { derecesine göre değerlendirebilme ihtimalleri }\end{array}$ & 3 \\
\hline 2 & ? & - Sınava odaklı ve planlı bir eğitim süreci olmasının etkisiyle çalışma & 2 \\
\hline \multirow[t]{2}{*}{3} & ? & - Öğrenilenleri meslek hayatında kullanma noktasında tam emin olamama & 2 \\
\hline & & Toplam: & 7 \\
\hline \multicolumn{4}{|c|}{ OLUMSUZ DURUMLAR } \\
\hline 1 & $\Theta$ & $\begin{array}{l}\text { - Öğretim elemanlarının öğrencilerle yeterince etkili iletişim kuramamaları sonucunda } \\
\text { sosyal yalıtılmış hissedebilme ihtimalleri }\end{array}$ & 5 \\
\hline 2 & $=0$ & - Öğretim elemanlarını pedagojik açıdan yetersiz görme & 2 \\
\hline 3 & $=$ & - Diğer öğrencilerle iletişim kuramama & 1 \\
\hline 4 & $=$ & - Öğretim elemanlarının öğrencilerin performanslarını gözlemleyememesi & 4 \\
\hline 5 & $=$ & - Teknik altyapının yetersiz olması & 3 \\
\hline 6 & $=$ & $\begin{array}{l}\text { - Öğretim elemanının tavrına bağlı olarak çevrimiçi öğrenme sürecinde başka şeylerle } \\
\text { ilgilenme }\end{array}$ & 2 \\
\hline 7 & $\theta$ & - Edinilen bilgilerin meslek hayatlarına transfer etmede yetersiz hissetme & 2 \\
\hline 8 & $=$ & - Mesleki konularda diğer insanlara yol göstermede yetersiz hissetme & 1 \\
\hline & & Toplam: & 20 \\
\hline
\end{tabular}

Bulgular bölümündeki veriler kategorilere ayrılarak Tablo 9 oluşturulmuştur. Tablo 9 incelendiğinde çevrimiçi ortamda öğrenmeye hazır bulunuşluk ile ilgili olarak toplamda 68 olumlu düşünce, yedi nötr düşünce, 20 tane de olumsuz düşüncenin olduğu görülebilir. 
Öğretmen adaylarının verdikleri yanıtların çevrimiçi öğrenmeye hazır bulunuşluğun alt boyutlarına göre olumlu, nötr ve olumsuz şekilde kategorize edilerek sunulduğu Tablo 10 aşağıda yer almaktadır.

Tablo 10. Katılımcıların Çevrimiçi ortamda öğrenmeye hazır bulunuşlukları noktasındaki olumlu, nötr ve olumsuz düşüncelerinin alt boyutlara göre dağılımı.

\begin{tabular}{lcccccccc}
\hline & \multicolumn{2}{c}{$\begin{array}{c}\text { Olumlu } \\
\text { durumlar }\end{array}$} & \multicolumn{2}{c}{$\begin{array}{c}\text { Nötr } \\
\text { durumlar }\end{array}$} & \multicolumn{2}{c}{$\begin{array}{c}\text { Olumsuz } \\
\text { durumlar }\end{array}$} & \multicolumn{2}{c}{ Toplam } \\
\cline { 2 - 9 } & $\mathrm{N}$ & $\%$ & $\mathrm{~N}$ & $\%$ & $\mathrm{~N}$ & $\%$ & $\mathrm{~N}$ & $\%$ \\
\hline İletişim özyeterliliği & 26 & 83.9 & 0 & 0 & 5 & 16.1 & 31 & 100 \\
Küumsal Destek & 18 & 58.0 & 3 & 9.7 & 10 & 32.3 & 31 & 100 \\
Öğrenme öz yönlendirmesi & 11 & 73.3 & 2 & 13.3 & 2 & 13.3 & 15 & 100 \\
Öğrenmeyi transfer öz yeterliliği & 13 & 72.2 & 2 & 11.1 & 3 & 16.7 & 18 & 100 \\
\hline Toplam & 68 & 71.6 & 7 & 7.4 & 20 & 21.0 & 95 & 100 \\
\hline
\end{tabular}

Tablo 10 incelendiğinde, İletişim öz yeterliliği ile ilgili olarak 26 olumlu, beş olumsuz düşüncenin olduğu görülür. İletişim öz yeterliliği ile ilgili olarak katılımcılar \% 83.9 oranında olumlu, \%16.1 oranında olumsuz görüş bildirmişlerdir. Kurumsal destek ile ilgili olarak 18 (\%58) olumlu, 3 (\%9.7) nötr, $10(\% 32.3)$ olumsuz düşünce ifade etmişlerdir. Çevrimiçi ortamda öğrenme öz yönlendirmesi için 11 (\%73.3), 2 (\%13.3) nötr, 2 (\%13.3) olumsuz düşünce ifade etmişlerdir. Öğrenmeyi transfer öz yönlendirmesi boyutu ile ilgili olarak ise 13 (\%72.2) olumlu, 2 (\%11.1) nötr, 3 (\%16.7) olumsuz durum ifade etmişlerdir. Toplama bakıldığında ise $68(\% 71.6)$ olumlu, $7(\% 7.4)$ nötr ve $20(\% 21)$ olumsuz ifadenin olduğu görülmektedir.

\section{Tartışma ve Sonuç}

Öğretmen adayları ile çevrimiçi ortamda öğrenme hazır bulunuşlukları hakkında yapılan görüşmeler sonucunda bu konu hakkındaki görüşleri olumlu, olumsuz ve nötr olmak üzere üç kategori altında değerlendirilmiştir. Olumlu ve olumsuz ifadelerin oranına bakıldığında (bakınız Tablo 9) olumlu ifadelerin olumsuzların yaklaşık üç buçuk katına yakın 
oranda olduğu tespit edilmiştir. Bu sonuçtan yola çıkarak katılımcıların çevrimiçi ortamda öğrenmeye hazır bulunuşluklarının yeterli düzeyde olduğu yorumu yapılabilir.

Öğretmen adayları ile yapılan görüşmeler "İletişim özyeterliliği”, "Kurumsal destek”, “Öğrenme öz yönlendirmesi” ve “Öğrenmeyi transfer öz yeterliliğgi” alt boyutları kapsamında yürütülmüştür. Alt boyutlar için olumlu ve olumsuz düşüncelerin oranı analiz edildiğinde ise katılımcılar oran olarak en çok iletişim öz yeterliliği boyutunda olumlu ifadeler kullanmışlardır (\%83.9). Çevrimiçi ortamdaki iletişim öz yeterliliği boyutu, çevrimiçi iletişim araçlarını kullanma, bu ortamda kendini ifade etme, çevrimiçi ortamda soru-cevap etkinliklerine ve tartışmalara katılma ile ilgili durumları barındırmaktadır. Öğrenci açısından başarılı bir öğrenme süreci için çevrimiçi teknolojileri rahat kullanım (Song, Singleton, Hill \& Koh, 2004) ve öğrenmeye katılım düzeyi (Park \& Choi, 2009) önemli unsurlardandır. Çevrimiçi öğrenmeye hazır bulunuşluk arttıkça bu ortamdaki etkileşim de artmaktadır (Kaymak \& Horzum, 2013). Bu çalışma kapsamında iletişimle ilgili olarak elde edilen yüksek orandaki olumlu ifadeler, katılımcıların etkileşimli bir çevrimiçi öğrenmeye hazır oldukları şeklinde yorumlanabilir.

Çalışma kapsamında elde edilen bulgular kapsamında oran olarak en yüksek olumsuz ifadeler kurumsal destek alt boyutu için dile getirilmiştir (\%32.3). Bu ifadelere bakıldığında bunların, diğer insanları değerlendirme, insanların birbirine olan bakış açıları ve teknik altyapı ile ilgili oldukları görülür. Bu veri ile tutarlılık gösterir şekilde, Keramati, Afshari-Mofrad \& Kamrani (2011) yaptıkları çalışmada çevrimiçi öğrenme ortamlarında en önemli zorluk olarak internet hızı gibi teknik sıkıntıların en başta yer aldığını ifade etmişlerdir. Öğrencilerin çevrimiçi öğrenme ortam kabulleri için algıladıkları kullanışlılık (Teo, 2010) göz önünde bulundurulması gereken bir unsurdur ve topluluk hisleri (öğretim elemanı, öğretim içeriği ve 
diğer öğrencilerle olan iletişim) bu ortamda gerçekleşen öğrenme sürecinin değerlendirilmesi noktasında göz önünde bulundurulmalıdır (Garrison, Anderson, \& Archer, 2000). İnsanlar arası ilişkilerin ve teknik donanımın söz konusu olduğu bir ortamda olumsuz bazı durumların olması olağan görülmektedir. Kurumsal destek ile ilgili olumlu düşüncelerin oranına (\%58) bakıldığında ise bunun çevrimiçi ortam öğrenmesine hazır bulunuşluk noktasında yeterli bir seviyede olduğu düşünülebilir.

Öğrenme öz yönlendirmesi ve Öğrenmeyi transfer öz yeterliliği boyutlarına ilişkin olumlu ve olumsuz ifadelerin oranlarına bakıldığında, bu boyutlarda da olumlu ifadelerin olumsuzlara göre fazla olduğu görülebilir. Çevrimiçi öğrenme ortamlarında, öğrencilerin kendi öğrenmeleri ile ilgili sorumlulukları artmaktadır (Lin \& Hsieh, 2001) ve öz yönlendirme konusundaki düşünceleri hazır bulunuşlukları noktasında daha bir önem kazanmaktadır. Öğrenme öz yönlendirmesi boyutu öğrencilerin kendi öğrenme süreçlerini yönetme yeterliliklerini kapsamaktadır. Geleneksel öğrenme ortamından farklı bir öğrenme ortamı olan çevrimiçi öğrenme ortamında öğrencilerin kendi öğrenmelerini yönetebilme noktasında yoğunluklu olarak olumlu ifadeler kullanmaları böyle bir öğrenme sürecine hazır bulunuşluk noktasında geçerli bir veri olarak değerlendirilmektedir. Benzer durum öğrenmelerin meslek hayatına yansıtılabilmesine ilişkin öz yeterlilik düzeyini yansıtan Öğrenmeyi transfer öz yeterliliği boyutu için de söylenebilir. Geçmiş deneyimlere sahip erişkin öğrenenler bağımsız şekilde edindikleri bilgileri başka ortamlara taşıyabilirler (Cercone, 2008). Ders içeriği tatmin edici olduğunda ve kendi yaşamları ile ilgili olduğunda dersi daha çok benimseme eğilimindedirler (Park \& Choi, 2009). Öğrenmeyi transfer öz yeterliliği boyuta ilişkin olumlu ifadelerin oranının çok olması öğrencilerin öğrendiklerini meslek yaşamlarına yansıtabilme öz yeterliklerinin çok olduğunun göstergesi olarak düşünülebilir. Dolayısıyla çevrimiçi ortam öğrenmesine hazır bulunuşluk bakımından da geçerli bir bilgi olarak değerlendirilmektedir. 


\section{Makalenin Bilimdeki Konumu (Yeri)}

Bilgisayar ve Öğretim Teknolojileri Eğitimi Bölümü

\section{Makalenin Bilimdeki Özgünlüğü}

Literatürde çevrimiçi öğrenme ortamları ile ilgili yapılan çalışmaların bu ortam öğrenmelerinin verimliliği ve bu ortamlarda yapılandırmacı yaklaşımın çeşitli yöntemlerinin kullanımı ile ilgili oldukları görülmektedir. Çağdaş öğrenme ortamları öğrenci odaklı olarak düzenlenmektedir. Çevrimiçi öğrenme ortamları için de bu durum geçerlidir ve bu ortamlardaki öğrenme sürecinin sağlıklı şekilde gerçekleşebilmesi için öğrenci hazır bulunuşluğu önemli bir değişken olarak karşımıza çıkmaktadır. Bu araştırma nitel araştırma yöntemleri ile öğrenci hazır bulunuşluğunu derinlemesine ortaya koymayı amaç edinerek bilime katk1 sunabilecektir.

\section{Kaynaklar}

Cercone, K. (2008). Characteristics of adult learners with implications for online learning design. AACE Journal, 16(2), 137-159.

Chen, H. C., Holton III, E. F., \& Bates, R. (2005). Development and validation of the learning transfer system inventory in Taiwan. Human Resource Development Quarterly, 16(1), $55-84$

Darab, B., \& Montazer, G. A. (2011). An eclectic model for assessing e-learning readiness in the Iranian universities. Computers \& Education, 56(3), 900-910.

Garrison, D. R., Anderson, T., \& Archer, W. (2000). Critical inquiry in a text-based environment: computer conferencing in higher education. The Internet and Higher Education, 2(2-3), 87-105. 
Horzum, M. B., Kaymak, Z. D., \& Gungoren, O. C. (2015). Structural equation modeling towards online learning readiness, academic motivations, and perceived learning. Educational Sciences: Theory and Practice, 15(3), 759-770.

Hrtoňová, N., Kohout, J., Rohlíková, L., \& Zounek, J. (2015). Factors influencing acceptance of e-learning by teachers in the Czech Republic. Computers in Human Behavior, 51, 873-879.

Hung, M. L. (2016). Teacher readiness for online learning: Scale development and teacher perceptions. Computers \& Education, 94, 120-133.

Hung, M. L., \& Chou, C. (2015). Students' perceptions of instructors' roles in blended and online learning environments: A comparative study. Computers \& Education, 81, 315325.

Ilgaz, H., \& Gülbahar, Y. (2015). A snapshot of online learners: e-readiness, e-satisfaction and expectations. The International Review of Research in Open and Distributed Learning, 16(2). 171-187.

Joo, Y. J., Joung, S., \& Sim, W. J. (2011). Structural relationships among internal locus of control, institutional support, flow, and learner persistence in cyber universities. Computers in Human Behavior, 27(2), 714-722.

Kaymak, Z. D. \& Horzum, M. B. (2013). Çevrimiçi öğrenme öğrencilerinin çevrimiçi öğrenmeye hazır bulunuşluk düzeyleri, algıladıkları yapı ve etkileşim arasındaki ilişki. KUYEB, 13(3), 1783-1797. 
Keramati, A., Afshari-Mofrad, M., \& Kamrani, A. (2011). The role of readiness factors in Elearning outcomes: An empirical study. Computers \& Education, 57(3), 1919-1929.

Kırmız1, Ö. (2015). The influence of learner readiness on student satisfaction and academic achievement in an online program at higher education. Turkish Online Journal of Educational Technology-TOJET, 14(1), 133-142.

Lin, B., \& Hsieh, C. T. (2001). Web-based teaching and learner control: A research review. Computers \& Education, 37(3), 377-386.

Loyens, S. M., Magda, J., \& Rikers, R. M. (2008). Self-directed learning in problem-based learning and its relationships with self-regulated learning. Educational Psychology Review, 20(4), 411-427.

Park, J. H., \& Choi, H. J. (2009). Factors influencing adult learners' decision to drop out or persist in online learning. Educational Technology \& Society, 12(4), 207-217.

Smart, K. L., \& Cappel, J. J. (2006). Students' perceptions of online learning: A comparative study. Journal of Information Technology Education, 5(1), 201-219.

Song, L., Singleton, E. S., Hill, J. R., \& Koh, M. H. (2004). Improving online learning: Student perceptions of useful and challenging characteristics. The internet and higher education, 7(1), 59-70.

ŠUmak, B., HeričKo, M., \& PušNik, M. (2011). A meta-analysis of e-learning technology acceptance: The role of user types and e-learning technology types. Computers in Human Behavior, 27(6), 2067-2077. 
Talsik, E. (2015). The investigation of readiness for e-learning of pre-service music teachers in Turkey. Anthropologist, 21(1-2), 263-270.

Teo, T. (2010). Development and validation of the e-learning acceptance measure (ElAM). The Internet and Higher Education, 13(3), 148-152.

Xiong, Y., So, H. J., \& Toh, Y. (2015). Assessing learners' perceived readiness for computersupported collaborative learning (CSCL): A study on initial development and validation. Journal of Computing in Higher Education, 27(3), 215-239.

Yıldırım, A. ve Şimşek, H. (2000). Sosyal bilimlerde nitel araştırma yöntemleri. (2. Baskı). Ankara: Seçkin Yayınevi.

Yıldırım, A. ve Şimşek, H. (2006). Sosyal bilimlerde nitel araştırma yöntemleri. (6. Baskı). Ankara: Seçkin Yayınevi.

Zimmerman, B. J. (2000). Self-efficacy: An essential motive to learn. Contemporary educational psychology, 25(1), 82-91. 